\title{
Transducin-Like Enhancer Protein 4
}

National Cancer Institute

\section{Source}

National Cancer Institute. Transducin-Like Enhancer Protein 4. NCI Thesaurus. Code C115085.

Transducin-like enhancer protein $4(773 \mathrm{aa}, \sim 84 \mathrm{kDa})$ is encoded by the human TLE4 gene. This protein plays a role in the repression of both transcription and signal transduction. 